\title{
Development of Hematopoietic and Endothelial Cells from Human Embryonic Stem Cells: Lessons from the Studies using Mouse as a Model
}

\author{
Anna Jezierski ${ }^{1}$, Albert Swedani $^{1}$, and Lisheng Wang ${ }^{1,2,3,{ }^{*}}$ \\ ${ }^{1}$ Department of Biochemistry, Microbiology and Immunology, ${ }^{2}$ Stem Cell Biology \\ Group, Ottawa Health Research Institute, ${ }^{3}$ Ottawa Institute of Systems Biology, \\ University of Ottawa, Ottawa, Canada \\ E-mail: Iwang@uottawa.ca
}

Received August 14, 2007; Accepted November 21, 2007; Published December 10, 2007

The current progress using the human embryonic stem cell (hESC) model system has provided much insight into the early origins of the hematopoietic and endothelial lineages, particularly the elusive hemangioblast. Recently, the cellular hierarchy and molecular regulation controlling hematopoietic commitment have been further elucidated. These findings not only provide new insights into early human development, but also advance the knowledge required to develop techniques capable of generating a given cell type for potential clinical applications. This review will focus on the latest advances using the hESC model system, capitalizing on the well-established mouse embryonic stem cell model system, as a means to investigate the lineage commitment events underlying the early embryonic development of human hematopoietic and endothelial cells.

KEYWORDS: human embryonic stem cells, hematopoiesis, hemangioblast, endothelial precursors

\section{BACKGROUND}

Current knowledge of hematopoiesis (from the Greek hemato meaning "blood" and poiesis meaning "to make") and endothelial cell (i.e., cells lining the inside of blood vessels) development in the mammalian embryo is largely based on studies of the mouse system[1,2,3]. In general, during mammalian embryogenesis, hematopoiesis occurs transiently at a number of successive anatomical locations[4]. Primitive hematopoiesis occurs within the blood islands of the extraembryonic yolk sac. This early hematopoietic commitment is observed through the generation of primarily nucleated erythrocytes that express embryonic and fetal hemoglobins, and later some myeloid lineage and primitive macrophage cells[5]. These primitive erythroblasts have been shown to enucleate in circulation[6] and eventually switch towards a more mature (adult) hemoglobin expression pattern[7]. Simultaneously, endothelial cells have also been shown to emerge in the blood islands leading to concurrent vasculogenesis[8], which suggests that both lineages may be derived from a putative common precursor termed the hemangioblast. 
Definitive hematopoietic stem cells (HSC), which have self-renewal capacity and sustain blood cells throughout the lifetime of an individual, emerge independently within the intraembryonic aorta-gonadmesonophros (AGM) region[9]. These cells then colonize the fetal liver and give rise to all other hematopoietic lineages, including myeloid (red and white blood cells, platelets) and lymphoid lineages ( $\mathrm{T}$ and B lymphocytes, plasma cells). Although the developing fetal liver serves as the main hematopoietic organ of the fetus, the precise relative contribution of the AGM and yolk sac hematopoietic precursors to the developing HSC pool remains unclear[4]. Recent work, employing an in vivo cell tracing technique, has shown that hematopoietic precursors from the yolk sac migrate to the fetal liver and thymus, and that yolk sac blood islands contain precursors of adult HSC[10]. The placenta may also play a role in providing a microenvironment for developing HSCs, although its role in the generation of HSCs remains unknown[11]. Following birth, the bone marrow serves as the principal hematopoietic organ into adulthood. It sustains the life-long maintenance of HSCs and ensures continual provision of specialized mature blood cells.

Despite the well-characterized events underlying early hematopoiesis in the mouse, a clear understanding of human hematopoietic and endothelial development is lacking. The scarcity and ethical complications of using early-stage human embryos, as well as the narrow time frame during which hematopoietic and endothelial development is initiated, have significantly hindered our understanding of these early embryonic events. The emergence of human embryonic stem cells (hESCs) provides a unique model system to study the earliest events of human development that are otherwise difficult to access in vivo.

\section{EMBRYONIC STEM CELLS: A POWERFUL TOOL TO RECAPITULATE IN VIVO HEMATOPOIETIC AND ENDOTHELIAL DEVELOPMENT}

\section{Mouse ESCs Pave the Way for hESCs in the Study of Hematopoietic and Endothelial Development}

Prior to the establishment of hESC lines (1998), studies using mouse ESCs (mESCs) produced a wealth of knowledge regarding early developmental decisions pertaining to embryonic hematopoietic and endothelial development in vitro. Keller and colleagues pioneered the use of differentiating mouse embryoid bodies (mEBs, formed by cellular aggregation of mESCs) as a tool to study early hematopoiesis. Of significance has been the capacity of mESCs to differentiate into hematoendothelial precursors, which in turn, recapitulate in vivo mouse embryonic hematopoiesis[12,13,14,15]. Moreover, the temporal appearance of hematopoietic and endothelial precursors, in addition to the differential expression pattern of mesodermal, hematopoietic, and endothelial genes in developing mEBs, have been well characterized and shown to imitate normal embryogenesis[16,17,18,19,20] (reviewed by Keller[21]).

Employing mESCs to the study of hematopoietic and endothelial specification in vitro paved the way for the use of hESC as a means to elucidate the human hematopoietic and endothelial development. hESCs are derived from the inner cell mass of blastocyst-stage embryos[22]. These cells, which are capable of self-renewal and long-term propagation, maintain karyotypic integrity in culture and possess the developmental potential to differentiate into derivatives of all three embryonic germ layers: endoderm, ectoderm, and mesoderm[22]; hence, giving rise to almost any tissue of the body. Of these layers, the mesoderm is capable of further development into muscle, skeleton, and endothelial and hematopoietic cells. Under appropriate culture conditions, by either cellular aggregation (hEB formation)[23,24,25,26, $27,28,29]$ or coculture with stromal cells[30,31], hESCs have the ability to differentiate into multiple hematopoietic lineages[23,24,25,26,30,31], as well as endothelial cells[25,27,28,29,32]. In vivo transplantation results suggest that hESCs may also give rise to hematopoietic stem/progenitor cells[33,34,35]. Based on these biological characteristics, hematopoietic and endothelial differentiation of hESCs recapitulates many aspects of embryonic development and provides an in vitro model[21] for studies that could not otherwise be well examined in the human embryo. The ability to decipher the 
mechanisms controlling germ layer specification, cellular commitment, lineage restriction, and terminal differentiation of hESCs will eventually allow scientists to direct the differentiation of hESCs into specific cell types for cell replacement therapy.

\section{Similarities and Differences between Mouse and Human ESCs}

Although there is a great deal of similarity between the technical aspects of mouse and human ESC maintenance and differentiation, it is important to note that the knowledge derived from one species cannot be arbitrarily applied to another. Fundamental differences exist between mouse and human developmental hematopoiesis. Most notably, humans contain an anatomically more complex primary and secondary yolk sac in addition to a shortened yolk sac phase[36] and earlier onset of medullary hematopoiesis[37].

In addition, established maintenance and differentiation strategies for mESCs differ significantly from those for hESCs (summarized in Table 1). For example, basic fibroblast growth factor (bFGF), an essential growth factor for the maintenance of hESCs[38,39,40,41], stimulates mESC differentiation into neural tissues[42]. Bone morphogenetic protein 4 (BMP4), an essential factor for mESC self-renewal[43], induces hESC differentiation[41,44]. Activin A (a member of the transforming growth factor- $\beta$ [TGF- $\beta$ ] family) maintains hESCs, but not mESCs, by regulating bFGF and BMP4 pathways[45,46,47,48].

TABLE 1

Differences between Undifferentiated Human and Mouse ESCs

\begin{tabular}{lcc}
\hline Proteins and Functions & Human ESCs & Mouse ESCs \\
\hline Leukemia inhibitory factor (LIF) receptor & Absence & Presence \\
LIF function & No effect & Maintenance \\
Bone morphogenetic protein 4 (BMP4) & Differentiation & Maintenance \\
Basic fibroblast growth factor (bFGF) & Maintenance & Differentiation \\
Transformation growth factor (TGF- $\beta$ ) & Maintenance & Differentiation \\
Activin A & Maintenance & Differentiation \\
SSEA-1 & Absence & Presence \\
SSEA-3 & Presence & Absence \\
SSEA-4 & Presence & Absence \\
Flk1/KDR & Presence $(\sim 15 \%$ of hESCs) & Absence \\
\hline
\end{tabular}

* $\quad$ Reference: $[22,25,26,41,43,47,48,57,111,112,113,114,115,116,117]$.

Furthermore, hESCs are also insensitive to leukemia inhibitory factor (LIF), a growth factor essential for the maintenance of mESCs[22,49]. LIF and related cytokines function by activating signal transducer and activator of transcription (STAT3) via the gp130 receptor[50]. BMP4 blocks differentiation by inducing the expression of inhibitor of DNA binding/differentiation (Id) proteins, which enables mESC self-renewal in response to LIF/STAT3[43]. In contrast to mESCs, cellular interplay and paracrine signaling may be required for the self-renewal and pluripotency of hESCs[51]. For example, inhibition of bFGF and TGF- $\beta$, which instruct hESC differentiation, is balanced by self-renewal signals controlled by insulin growth factor (IGF)[51]. IGF seems to be produced in response to bFGF induction by hESCderived fibroblast cells, which provide supportive factors that sustain the defining properties of hESCs[51]. In addition to the aforementioned differences, certain cell surface markers and transcriptional factors are also differentially expressed in mESCs and hESCs, such as stage-specific embryonic antigen 
(SSEA) -1, -3, and -4. SSEA-1 is exclusively expressed in mESCs, whereas, SSEA-3 and -4 are exclusively expressed in hESCs.

Such differences between mouse and human ESCs may reflect real differences between species or the precise embryonic origin of both cell types. Currently derived pluripotent mouse EpiSCs (postimplantation epiblast-derived stem cells that generate the embryo proper) share patterns of gene expression and signaling responses with hESCs[47,48]. The Activin/Nodal pathway that was important in the maintenance of hESCs is also crucial for the self-renewal of the mouse EpiSCs[47,48]. Hence, further study and comparison of EpiSCs and hESCs may contribute to the understanding of early human development.

Despite the differences between mouse and human ESCs, different hESC lines manifest a remarkable degree of phenotypic similarity and harbor a common set of markers, as recently characterized by the International Stem Cell Initiative[52]. This comparative study covered 59 different hESC lines maintained in 17 laboratories scattered across 11 countries, the largest cross-sectional analysis to date. Despite unique genetic backgrounds, derivation and maintenance techniques under varying culture and passage conditions, the 59 hESC lines examined revealed a great deal of similarity. The degree of phenotypic convergence within hESC lines worldwide is reassuring and substantiates the use of hESCs as a powerful tool to study human hematopoiesis and endothelial specification.

\section{SURROGATE MARKERS USED IN THE STUDY OF HEMATOPOIETIC AND ENDOTHELIAL DEVELOPMENT}

In addition to functional assays, surrogate markers, such as cell surface proteins and gene expression profiles, have been used to characterize the successive development of hematopoietic and endothelial precursors, and subsequently committed cell lineages. These surrogate markers can be analyzed by flow cytometry, PCR, and imaging methods.

Commonly, early human endothelial and hematopoietic precursors have been characterized based on the expression of KDR (mouse counterpart Flk-1, also known as vascular endothelial growth factor receptor 2), CD34 and CD31 (platelet endothelial cell-adhesion molecule-1, PECAM-1), together with the absence of pan-leukocyte marker CD45[25,26,27,29,37,53,54]. Recently, leukosialin (CD43) has been proposed as an alternative marker for hESC-derived hematopoietic stem/progenitor cells[55]. Following hESC differentiation, Vodyanik et al. found that $\mathrm{CD} 34^{+} \mathrm{CD} 43^{+}$-derived cells were hematopoietic cells, $\mathrm{CD}^{+} 4^{+} \mathrm{CD} 43^{-} \mathrm{CD} 31^{+} \mathrm{KDR}^{+}$cells were endothelial cells, and $\mathrm{CD}^{+} 4^{+} \mathrm{CD} 43^{-} \mathrm{CD}^{-} 1^{-} \mathrm{KDR}^{-}$cells were mesenchymal cells[55].

Multiple markers have been used for the characterization of endothelial precursors and mature cells. Expression of vascular endothelial cadherin (VE-cadherin, CD144) alone[56,57] or together with the ability to take up Dil-labeled acetylated low-density lipoprotein (Dil-Ac-LDL) [56,58] has been used as a marker for the identification of endothelial precursors. CD31, CD34, Flk-1, and von Willebrand factor (vWF) are generally used for the identification of endothelial precursor and/or mature endothelial cells[57,58,59]. One of the commonly used markers for discriminating committed endothelial from hematopoietic cells is VE-cadherin[59]. Committed nucleated hematopoietic cells express CD45, but not VE-cadherin. In addition to the cell surface proteins, a large number of signaling molecules and transcription factors are involved in hematopoietic and endothelial development (such as KDR/Flk-1, ckit, Scl/Tal1, Tie2, Gata2, and Runx1, etc.) (reviewed[21,60]).

\section{COMMON PRECURSOR HYPOTHESIS: THE HEMANGIOBLAST}

A central theme surrounding the emergence of the hematopoietic system is the existence of a common bipotent precursor with endothelial properties. Endothelial and hematopoietic cells, in the developing vertebrate embryo, emerge in close spatial and temporal association in the extraembryonic yolk sac blood 
islands at the $3^{\text {rd }}$ week of gestation in the human embryo and at embryonic day 7.5 in the mouse embryo[53,61]. These blood islands consist of aggregates of mesodermal cells that contribute to both the vascular and hematopoietic system. The cells at the periphery develop into endothelial cells, whereas the inner cells develop into hematopoietic cells[62]. This close developmental proximity of both lineages, initially observed in the avian embryo[63], led to the proposition of a common mesodermal precursor, termed the hemangioblast, capable of giving rise to both endothelial and hematopoietic cells[63,64]. Indeed, more recent mapping studies in the developing mouse embryo reveal that the hemangioblast arises as a transient mesodermal population within the posterior region of the primitive streak[20].

The hemangioblast was initially identified using the mESC differentiation model[13,16,57] and later in vivo in the mouse embryo[20], in zebrafish[65], and recently in the hESC model[25,26,27]. Although the precise origin of hematopoietic and endothelial lineages remains a topic of ongoing debate, the concept that endothelial and hematopoietic cells share a common bipotent precursor has been intensely pursued (reviewed[66,67,68]). In addition to contributing to the understanding of early embryonic development, the existence of the hemangioblast is particularly promising as an alternative source of hematopoietic and endothelial cells for cell replacement therapies.

\section{PROPOSED DEVELOPMENTAL HIERARCHY OF ENDOTHELIAL AND HEMATOPOIETIC CELLS: THE MOUSE MODEL}

Studies in the mouse have suggested that both yolk sac and AGM-derived precursors are the progeny of a bipotent hemangioblast (reviewed[21]). Evidence supporting this common origin of endothelial and hematopoietic cells arose through the identification of a blast colony-forming cell (BL-CFC) derived from mEBs and later the mouse embryo[13,16,20,57].

BL-CFCs have the potential to differentiate along both lineages in response to VEGF (vascular endothelial growth factor, a ligand for the receptor tyrosine kinase, Flk-1/KDR)[69,70] prior to the onset of primitive erythropoiesis[13,16,20]. These VEGF-responsive precursors develop within the mammalian yolk sac blood islands as a subset of mesoderm (Brachyury ${ }^{+}$) cells expressing Flk-1[17,20,71]. BL-CFCs give rise to primitive and definitive hematopoietic as well as endothelial precursors[13,16,57,71,72] (Fig. 1). Targeted deletion of Flk-1 in mESCs dramatically disrupted blood vessel formation and failed to contribute to primitive and definitive hematopoiesis in vivo[73,74]. Further, in vitro and in vivo studies have shown that Flk-1 is required for the migration and expansion of the hemangioblast[73,74,75,76] from the primitive streak to the yolk sac, a site permissive for hematopoiesis[73,74,75,76,77].

In addition to hematopoietic and endothelial cells, the BL-CFC also has the potential to give rise to other lineages under different culture conditions, such as smooth muscle cells[75]. Cell-lineage tracing experiments in mice have further demonstrated that cardiac lineages, endocardium, and myocardium develop from an intermediate cell population that expresses Flk-1[78,79,80]. Myocardial and endothelial lineages, as well as cardiomyocytes, have also been shown to arise from Flk- $1^{+}$precursors isolated from differentiated mouse ESC and early embryos[78,81]. These Flk- $1^{+}$precursors of cardiac potential, termed cardiovascular colony-forming cells (CV-CFCs), might arise from an intermediate Flk- $1^{+}$cell population that emerges later and is distinct from the $\mathrm{Flk}-1^{+}$population with hemangioblastic properties[19]. The finding that CV-CFC precursors contain both cardiac and vascular potential[19] sustains the belief that cardiac lineages develop from a precursor with endothelial potential[82,83]. Hence, it appears that the BL-CFC, which gives rise to both hematopoietic and vascular lineages of the blood islands, precedes the development of the CV-CFC that generates the myocardial and endothelial lineages [19]. Complementary studies have shown that Flk- $1^{+} \mathrm{CD} 31^{+} \mathrm{VE}$-cadherin ${ }^{-}$cells could act as cardiohemangioblasts to form cardiac cells[84], which is consistent with the findings that VEGF-induced cardiomyocyte differentiation of mESCs occurs via the activation of Flk-1 and Flt1 (vascular endothelial growth factor receptor 1)[85]. Collectively, these results suggest that Flk $-1^{+}$cells may represent a multipotent mesodermal precursor that later specializes into different mesodermal lineages according to the position in the embryo. 


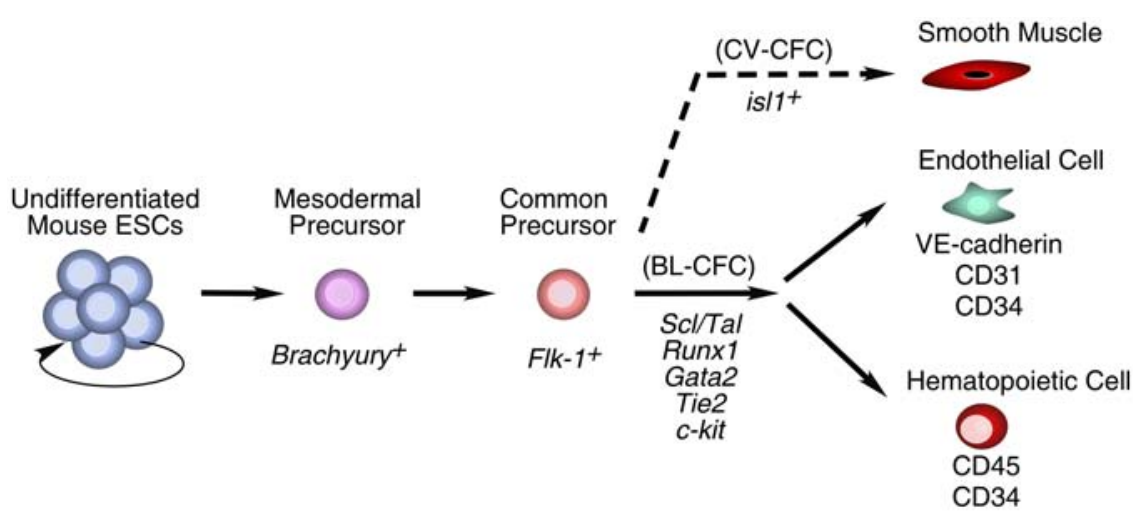

FIGURE 1. Proposed mouse developmental hierarchy of mesodermal cells. A subset of Brachyury positive cells, expressing Flk-1, emerges during mesodermal specification of differentiating mESCs. These Flk- $1^{+}$cells are capable of giving rise to BL-CFCs, which can further develop into hematopoietic and endothelial cells, as well as smooth muscle cells. Consequently, the BL-CFC has been proposed to represent an in vitro equivalent of the hemangioblast. Furthermore, the same subset of Flk- $1^{+}$cells can also give rise to CV-CFCs, which are endowed with cardiac and vascular potential. These CV-CFCs emerge later and are distinct from the BL-CFCs. Collectively, the BLand CV-CFC may represent a transient precursor population, capable of commitment to the hematopoietic, endothelial, smooth muscle, and cardiac lineages dependent on the temporal developmental expression and activation of different transcription factors (such as Scl/Tal1, Runx1, Gata2, Tie2, c-kit, and isl, respectively). Signaling molecules and transcription factors are indicated in italics, whereas cell surface proteins are indicated in plain text.

Recently, Moretti et al. defined a mESC-derived multipotent Isl1 ${ }^{+}$(LIM-homeobox transcription factor islet-1) cardiovascular progenitor cell expressing Flk-1 capable of generating cardiac muscle, smooth muscle, and endothelial cells in vitro[86]. Endothelial cells were found to arise solely from Isl $1^{+}$Flk- $1^{+}$cells, representing a subset of more restricted progenitor cells, capable of generating endothelial and smooth muscle cells[86]. This result is in accordance with the observation that mESCderived Flk- $1^{+}$cells can differentiate in vitro and in vivo into two major components of the vascular system: endothelial and mural cells[87]. These Flk- ${ }^{+}$cells expressing PDGFR (platelet-derived growth factor receptor) $-\beta$ have the potential to differentiate into mural cells in the presence of PDGF[87,88]. Rolny et al. found that the expression of PDGFR- $\beta$ on $\mathrm{CD} 31^{+} \mathrm{CD} 41^{+} \mathrm{Flk}-1^{+}$early hematopoietic/ endothelial precursors regulates the vascular/hematopoietic development by affecting the differentiation rates of both endothelial and hematopoietic lineages[89]. In differentiating mESCs and yolk sac, activation of PDGFR- $\beta$ was found to promote endothelial, but suppress hematopoietic, differentiation[89].

Altogether, increasing evidence suggests that Flk-1 expression marks a broad spectrum of mesodermal precursors. Although, conventionally, Flk-1 was regarded as a putative hemangioblastic marker, it also marks a common multipotent mesodermal precursor that can give rise to cell types like smooth muscle, cardiac, and mural cells. This further specialization of subsets of Flk-1 expressing cells might occur via the activation of other lineage-specific transcription factors during development.

\section{TRANSITION TOWARDS hESCS IN STUDYING THE HEMANGIOBLAST}

Limited research with human embryos also suggests that human hematopoietic cells emerge in close vicinity to vascular endothelial cells during the early weeks of human gestation. Hematopoietic cell clusters were shown to arise from the AGM region between the $27^{\text {th }}$ and $40^{\text {th }}$ day of human development, through an intermediate blood-forming endothelium stage[53,61]. However, the cellular and molecular mechanisms associated with early human hematopoietic and endothelial genesis, prior to 3 weeks of 
gestation, remain elusive. The establishment of hESCs provides an alternative tool to tackle these questions.

A number of in vitro studies using hESCs also supports the hypothesis that hematopoietic and endothelial cells develop from a common precursor or from hemogenic (blood forming) endothelial cells[25,26,27,28,29,90,91,92]. Collectively, these studies have shown that: (1) the differentiation of hESCs into endothelial and hematopoietic cells follows a reproducible timing pattern[25,26,27, 28,29,30,32], (2) endothelial and/or hematopoietic cells develop from an intermediate precursor[25,26, $27,28,29]$, and that (3) these intermediate precursors are hemangioblasts[27] or primitive endothelial-like cells with hemangioblast properties[25,26] (see Fig. 2).

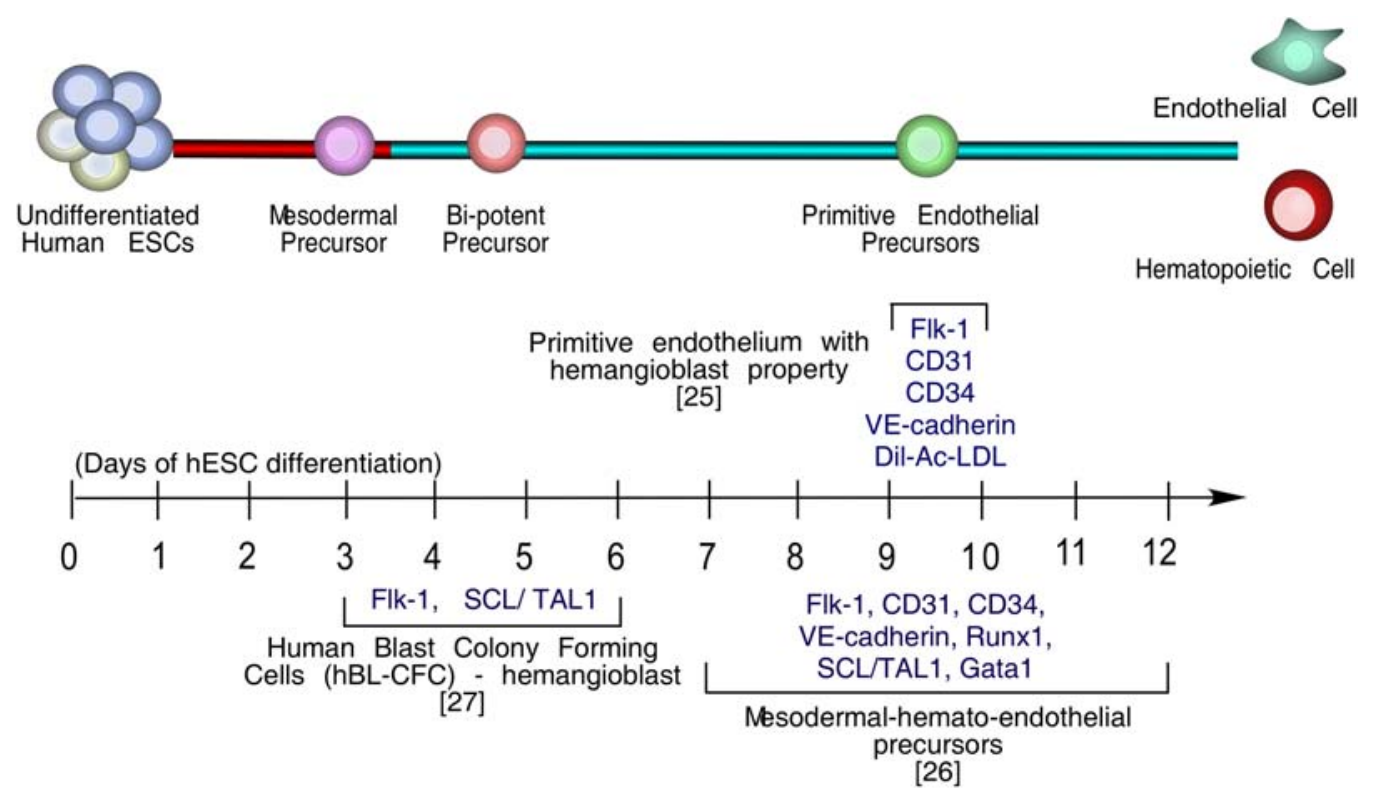

FIGURE 2. The schematic development of hESCs into hematopoietic and endothelial lineages. Two independent research groups have shown that hematopoietic and endothelial cells arise from an intermediate primitive endotheliallike or mesodermal hematoendothelial precursor with hemangioblast properties. Using an experimental approach similar to those employed in mESCs, the third research group recently demonstrated that a Flk- $1^{+}$progenitor, derived from 3- to 4-day-old differentiated hEBs, is capable of giving rise to a transient human blast colony-forming cell (hBL-CFC). These hBL-CFCs have hemangioblast properties and are capable of further development into hematopoietic and endothelial lineages. Since various research groups employ different experimental approaches, it remains unclear whether the same or distinct populations of bipotent precursors were examined.

Hematopoietic differentiation from hESCs, via spontaneous formation of hEBs, mimics the early events of human yolk sac blood development, through mesodermal-hemangioblast differentiation followed by primitive erythromyeloid hematopoiesis[26,92]. Early-stage primitive endothelial precursors, derived from day 9 to 10 of hEB differentiation, coexpress endothelial markers PECAM-1, Flk-1 and VEcadherin and are capable of Dil-Ac-LDL uptake, but lack CD45 expression[25]. This subpopulation of precursor cells, termed $\mathrm{CD} 45^{\text {neg }} \mathrm{PFV}$, was capable of endothelial maturation as well as hematopoietic development when cultured under appropriate conditions and as a result, proposed to represent bipotent precursors with hemangioblast properties (reviewed[93]). Similarly, an equivalent cell population was derived following coculture of hESCs with OP9 stromal cells for 8 to 9 days[31], or with mouse bone marrow stromal cells (S17) or mouse yolk sac ECs (C166) for 17 days[30]. Using a different approach, Zambidis et al. showed that "mesodermal-hemato-endothelial colonies" derived from cells isolated between day 7 to 12 of hEB differentiation (expressing CD34, CD31 and Flk-1) were both competent for endothelial maturation and endowed with blood-forming potential[26]. These results suggest that hemangioblasts, with primitive endothelial properties, may exist during early hESC differentiation. 
Despite these promising advances, a clonogenic bipotent human hemangioblast has remained elusive in the hESC culture. In the mouse developmental system, it is thought that the hemangioblast is likely contained within a subset of Flk-1 ${ }^{+}$mesoderm cells that can be efficiently enriched for in developing mEBs[71]. The observation that Flk- $1^{+}$cells emerge in early-somatic human embryos, at the beginning of blood vessel development, also suggests that Flk-1 plays a role in the regulation of human embryonic hematopoietic and vascular development[54]. In effect, Kennedy et al. recently identified Flk- $1^{+}$ precursors during early hEB differentiation capable of giving rise to blast colonies with both hematopoietic and endothelial potential[27]. These Flk-1 ${ }^{+}$BL-CFCs represent a transient cell population that develops between day 3 and 4 of hEB differentiation, preceding the development of the primitive erythroid precursors[27]. Since CD31 was first detected on a subpopulation of Flk- $1^{+}$cells at day 5, it may represent a distinct or earlier precursor population than the CD $45^{\text {neg }} \mathrm{PFV}$ precursors[25]. Two distinct populations of cells developed from the Flk- $1^{+}$BL-CFCs. One population showed hematopoietic potential capable of further development into primitive erythroid, macrophage, and endothelial cells, while the other population gave rise to only primitive erythroid and endothelial cells[27]. These results may characterize the earliest stage of hematopoietic and endothelial commitment through an intermediate hemangioblast population. However, due to various research groups employing different experimental approaches[25,26,27], it is not clear whether the same or different populations of potential bipotent precursors were examined.

Although precursors with hemangioblastic properties (CD45 ${ }^{\text {neg }} \mathrm{PFV}$ cells and Flk-1 ${ }^{+} \mathrm{BL}-\mathrm{CFC}$ ) have been demonstrated through the hEB differentiation system, large-scale generation or functional assessment of these putative hemangioblasts has not been achieved due to their rarity in culture. To circumvent this limitation, Lu et al. developed an in vitro differentiation method for generating large numbers of hemangioblasts from hESC-derived blast cells (hESC-BCs)[28]. These hESC-BCs developed from individual cells dissociated from early-stage hEBs ( 3 days) and plated in serum-free semi-solid blast-colony growth medium for 3 to 6 days. These hESC-BCs expressed several proteins associated with the hemangioblast, but not CD31, CD34, and Flk-1; that were shown to be expressed on the hemangioblast population by other groups[25,26,27]. Nevertheless, the hESC-BC-derived single-cell suspension in vitro gave rise to colonies of erythrocytes, granulocytes, macrophage, megakaryocyte, and multilineage hematopoietic as well as endothelial cells. In order to determine endothelial functionality in vivo, fluorescently labeled hESC-BC were injected into mice with ischemia-reperfusion injury to the retina where they localized to the site of injury in the damaged vasculature and appeared to participate in repair[28]. Since the expression of FLK-1, CD31, and CD144 appeared following induction towards endothelial cell differentiation, these hESC-BCs represent a distinct and even earlier population of cells than those reported recently by Kennedy et al.[27].

In contrast to the commonly used hEB differentiation approach, Wang et al. recently developed a culture system to differentiate hESCs into hematopoietic and endothelial lineages by by-passing hEB formation altogether[29]. To initiate differentiation, hESCs were plated on mouse embryonic fibroblasts in differentiation media. Following exposure to a cocktail of growth factors, hESC-derived CD34 ${ }^{+}$cells (of which a majority also coexpress $\mathrm{CD} 31^{+}$) purified following day 10 of differentiation were capable of giving rise to endothelial cells. These hESC-derived endothelial cells formed functional blood vessels in vivo for 150 days. Compared to earlier studies[32], these hESC-derived blood vessels integrated into the host vasculature and served as blood conduits. The hematopoietic potential of the derived hematopoietic cells was not further investigated in this study.

Although the concept of a hemangioblast is supported by the coexpression of a number of shared genes by both lineages, no unique surface marker currently exists that solely identifies this intermediate precursor. Recently, Zambidis et al. proposed that the BB9 monoclonal antibody[94], which was previously used to identify a subpopulation of human adult bone marrow-derived CD34 ${ }^{+}$precursor cells[95], could be used to identify a population of putative hemangioblasts. The emergence of BB9 expression directly correlated with the development of a hemangioblastic BL-CFC, prior to CD34 expression, following 6 to 10 days of hEB differentiation. CD34 was subsequently up-regulated upon further differentiation[94]. Sorted $\mathrm{BB} 9^{+} \mathrm{CD} 34^{+} \mathrm{CD} 45^{-}$or $\mathrm{BB}^{+} \mathrm{CD} 43^{+} \mathrm{CD} 45^{-} \mathrm{hEB}$ cells formed blast cells 
that gave rise to definitive AGM-type precursors as well as definitive type NK and B lymphocytes following culture on OP9 stromal layers[94]. However, more studies are required in order to validate whether BB9 represents an unequivocal hemangioblast marker.

If a unique surface marker for the hemangioblast can be identified, the current discrepancies in the kinetics of the hEB differentiation system will be clarified. These discrepancies are largely a result of different conditions used for mesoderm induction and hematopoietic specification. While Wang et al.[25] and Zambidis et al.[26] differentiated hEBs in medium containing fetal bovine serum and a cocktail of cytokines, Kennedy et al.[27] used a procedure that consisted of a serum-free medium and a mixture of cytokines followed by expansion of the hEB-derived single cells in serum-containing semi-solid medium. The use of different mixtures of cytokines and batches of fetal bovine serum may alter the kinetics of hEB differentiation and, hence, contribute to the variation between the different research groups.

\section{HEMANGIOBLAST: A RARE EVENT OF A COMMON PRECURSOR?}

During development, two main paradigms exist in defining the emergence of hematopoietic and endothelial lineages. First is the concept of the hemangioblast, while the second assumes that hematopoietic cells are derived from the primitive or hemogenic endothelium. The hemangioblast has been demonstrated in both mouse and human systems, although the mechanisms that regulate its development and differentiation are not well understood[16,17,20,25,27,57,76]. A major obstacle in characterizing the hemangioblast is its rare occurrence: an average of 33 hemangioblasts per mouse embryo[20], $0.33 \%$ (one in 300) in the mESC-derived precursors expressing Flk-1[96], 0.2\% (one in 500)[25] or 0.4-1.4\%[27] in the hESC-derived single precursors expressing Flk-1 or CD31. This scarcity of ESC-derived precursors may imply that not all hematopoietic and endothelial cells are developed from an intermediate hemangioblast population. In fact, recent studies in the mouse have shown that the yolk sac blood islands do not arise from a clonal bipotential precursor[97] and that endothelial precursors emerge from mesoderm prior to the development of the hemangioblast[98].

Furthermore, using multiple color tags to identify clonal precursors in vivo, as a means to delineate cell precursor-progeny relationships, Ueno and Weissman found that the blood islands within developing mouse embryos were polyclonal and not hemangioblastic in origin[97]. Although endothelial cells were found to be largely derived from $\mathrm{Flk}^{+} \mathrm{1}^{+}$precursors, following lineage-marking experiments, hematopoietic cells were not[97]. As such, it is probable that separate endothelial and hematopoietic precursors give rise to their respective cell fates, independent of an intermediate hemangioblastic stage and not necessarily concomitantly. Furuta et al. found that a considerable number of angioblasts could be detected 1 day prior to hematopoietic activity in early gastrulating mouse embryos[98]. Initial cell-lineage tracing of cells originating from the primitive streak to the yolk sac in mouse embryos also failed to reveal a common hematopoietic and endothelial precursor[99]. If this is indeed the case, then the close developmental association of the two lineages within the blood islands does not necessarily mean that they arise from a common precursor, but rather that the close association is needed for their further development and function[97]. The latter observation leads into the second developmental paradigm: the primitive or hemogenic endothelium, as originally proposed by Sabin[64]. A discrete subset of endothelial cells transiently exhibit blood forming potential during vertebrate development[53,61]. Although it remains unclear how great a potential the primitive or hemogenic endothelium might have, the environment sustained by functional endothelial cells during early development is essential for the correct differentiation of hematopoietic precursors.

Since conclusive evidence of an in vivo hemangioblast is dependent on direct lineage labeling in the intact embryo, these studies are unlikely to be carried out in the human embryo. Nevertheless, the emerging studies using hESCs lend support towards the hemangioblast theory[27,28], fueling the ongoing debate. 


\section{DEVELOPMENT OF HEMATOPOIETIC STEM/PROGENITOR CELLS FROM hESCS}

Although both mouse and human ESCs can be effectively differentiated into hematopoietic precursors in vitro, the ability to generate transplantable hematopoietic stem cells remains very challenging[100]. Commonly, HSCs are examined by reconstitution of lethally irradiated mouse bone marrow. A low-level and short-term hematopoietic reconstitution of lethally irradiated mouse hosts was reported over 10 years ago, suggesting that mouse ESCs may be capable of giving rise to HSCs[101,102,103]. A recent report from one group supported this observation and showed a robust engraftment (>70\%) at 20 weeks of intra bone marrow transplantation of mESC-derived hematopoietic cells into mice[104]. It would be very interesting to see whether such robust engraftment could be reproduced and the appropriate culture conditions for generating mESC-derived HSC defined.

In the hESC setting, a few research groups have currently reported that hESC-derived hematopoietic cells showed hematopoietic stem cell properties after transplantation into immunodeficient mice or fetal sheep[33,34,35]. Although the proliferation and migration was low, transplantation of CD45 ${ }^{\text {neg }} \mathrm{PFV}$ derived hematopoietic cells into immunodeficient mice after 8 weeks resulted in multilineage hematopoietic repopulation including myeloid, lymphoid, and erythroid lineages[33]. Similarly, Tian et al. found a low level of hESC-derived CD $45^{+} \mathrm{CD} 34^{+}$hematopoietic cells in the primary recipient mice and very low levels of human engrafts in the secondary recipients, indicating that long-term repopulating cells (HSC) from differentiated hESCs may exist[34]. Using the fetal sheep model, Narayan et al. recently demonstrated that hESC-derived hematopoietic cells (CD34 ${ }^{+} / \mathrm{Lin}^{-}$or $\mathrm{CD} 34^{+} / \mathrm{CD} 38^{-}$cells) are capable of engrafting primary recipients[35]. Secondary recipient engraftment was subsequently investigated and, similar to primary recipients, very low-levels of human engrafts were identified.

The limited capacity to engraft hESC-derived hematopoietic cells in animal transplantation models could be caused by an abnormal expression of gene profiles, such as an up-regulation of HoxB and a down-regulation of HoxA cluster genes[33]. Expression of HoxB4 enables in vitro differentiated mESCs to repopulate irradiated mice although with poor lymphoid reconstitution[105]. However, it is more likely that such limited success is due to the inadequacy of the in vitro microenvironmental niche, which characterizes hematopoietic development of hESCs. Further defining these niches will eventually allow researchers to generate desirable numbers of HSC for cell-based therapy.

\section{CONCLUDING REMARKS}

Although much progress has been made in recent years on the study of early hematopoietic and endothelial differentiation, using both mouse and human ESCs, the underlying mechanisms responsible for specifying hematopoietic and endothelial cell fates remain to be fully deciphered. Understanding the mechanisms that govern these cell fate decisions will ultimately lead to developing techniques for the induction of hESC differentiation towards desired cell lineages. Ideally, producing HSCs and endothelial precursors from tailored patient-hESCs would circumvent the lack of transplantable histocompatible cells. The current research progress in epigenetic reprogramming has shed light on this possibility. Three independent groups have reproduced Takahashi and Yamanaka's findings[106], and successfully engineered embryonic stem-like cells from normal mouse skin fibroblast cells[107,108,109]. By introducing just four pluripotency-associated transcription factors (Oct3/4, Sox2 \{known to be under strict epigenetic control during development[110]\}, c-Myc and Klf4) into mouse skin fibroblasts, researchers could produce cell lines with the properties of ESCs[106,107,108,109]. If this method can be transferred to humans in the future, patient-specific hESC and, subsequently, differentiated HSCs and endothelial precursors could be derived without the use of donated eggs or embryos. 


\section{ACKNOWLEDGMENTS}

This work is supported by an operating grant from the Canadian Institutes of Health Research (CIHR) MOP-158235, a CIHR New Investigator Award MSH-166732, and a fund from J.P. Bickell Foundation to L.W. The authors would like to thank Drs. P. Roy Walker and Li LI for their critical reading of the manuscript.

\section{REFERENCES}

1. Baron, M.H. (2005) Early patterning of the mouse embryo: implications for hematopoietic commitment and differentiation. Exp. Hematol. 33, 1015-1020.

2. Durand, C. and Dzierzak, E. (2005) Embryonic beginnings of adult hematopoietic stem cells. Haematologica 90, 100-108.

3. Dzierzak, E. (2005) The emergence of definitive hematopoietic stem cells in the mammal. Curr. Opin. Hematol. 12, 197-202.

4. Mikkola, H.K. and Orkin, S.H. (2006) The journey of developing hematopoietic stem cells. Development 133, 37333744.

5. McGrath, K.E. and Palis, J. (2005) Hematopoiesis in the yolk sac: more than meets the eye. Exp. Hematol. 33, 10211028.

6. Kingsley, P.D., Malik, J., Fantauzzo, K.A., and Palis, J. (2004) Yolk sac-derived primitive erythroblasts enucleate during mammalian embryogenesis. Blood 104, 19-25.

7. $\quad$ Kingsley, P.D., Malik, J., Emerson, R.L., Bushnell, T.P., McGrath, K.E., Bloedorn, L.A., Bulger, M., and Palis, J. (2006) "Maturational" globin switching in primary primitive erythroid cells. Blood 107, 1665-1672.

8. $\quad$ Eichmann, A., Yuan, L., Moyon, D., Lenoble, F., Pardanaud, L., and Breant, C. (2005) Vascular development: from precursor cells to branched arterial and venous networks. Int. J. Dev. Biol. 49, 259-267.

9. Pietila, I. and Vainio, S. (2005) The embryonic aorta-gonad-mesonephros region as a generator of haematopoietic stem cells. APMIS 113, 804-812.

10. Samokhvalov, I.M., Samokhvalova, N.I., and Nishikawa, S. (2007) Cell tracing shows the contribution of the yolk sac to adult haematopoiesis. Nature 446, 1056-1061.

11. Ottersbach, K. and Dzierzak, E. (2005) The murine placenta contains hematopoietic stem cells within the vascular labyrinth region. Dev. Cell 8, 377-387.

12. Keller, G., Kennedy, M., Papayannopoulou, T., and Wiles, M.V. (1993) Hematopoietic commitment during embryonic stem cell differentiation in culture. Mol. Cell. Biol. 13, 473-486.

13. Kennedy, M., Firpo, M., Choi, K., Wall, C., Robertson, S., Kabrun, N., and Keller, G. (1997) A common precursor for primitive erythropoiesis and definitive haematopoiesis. Nature 386, 488-493.

14. Nakano, T., Kodama, H., and Honjo, T. (1996) In vitro development of primitive and definitive erythrocytes from different precursors. Science 272, 722-724.

15. Wiles, M.V. and Keller, G. (1991) Multiple hematopoietic lineages develop from embryonic stem (ES) cells in culture. Development 111, 259-267.

16. Choi, K., Kennedy, M., Kazarov, A., Papadimitriou, J.C., and Keller, G. (1998) A common precursor for hematopoietic and endothelial cells. Development 125, 725-732.

17. Fehling, H.J., Lacaud, G., Kubo, A., Kennedy, M., Robertson, S., Keller, G., and Kouskoff, V. (2003) Tracking mesoderm induction and its specification to the hemangioblast during embryonic stem cell differentiation. Development 130, 4217-4227.

18. Robertson, S.M., Kennedy, M., Shannon, J.M., and Keller, G. (2000) A transitional stage in the commitment of mesoderm to hematopoiesis requiring the transcription factor SCL/tal-1. Development 127, 2447-2459.

19. Kattman, S.J., Huber, T.L., and Keller, G.M. (2006) Multipotent flk-1(+) cardiovascular progenitor cells give rise to the cardiomyocyte, endothelial, and vascular smooth muscle lineages. Dev. Cell 11, 723-732.

20. Huber, T.L., Kouskoff, V., Joerg Fehling, H., Palis, J., and Keller, G. (2004) Haemangioblast commitment is initiated in the primitive streak of the mouse embryo. Nature 432, 625-630.

21. Keller, G. (2005) Embryonic stem cell differentiation: emergence of a new era in biology and medicine. Genes Dev. 19, 1129-1155.

Thomson, J.A., Itskovitz-Eldor, J., Shapiro, S.S., Waknitz, M.A., Swiergiel, J.J., Marshall, V.S., and Jones, J.M. (1998) Embryonic stem cell lines derived from human blastocysts. Science 282, 1145-1147.

23. Cerdan, C., Rouleau, A., and Bhatia, M. (2004) VEGF-A165 augments erythropoietic development from human embryonic stem cells. Blood 103, 2504-2512.

24. Chadwick, K., Wang, L., Li, L., Menendez, P., Murdoch, B., Rouleau, A., and Bhatia, M. (2003) Cytokines and BMP-4 promote hematopoietic differentiation of human embryonic stem cells. Blood 102, 906-915.

25. Wang, L., Li, L., Shojaei, F., Levac, K., Cerdan, C., Menendez, P., Martin, T., Rouleau, A., and Bhatia, M. (2004) 
Endothelial and hematopoietic cell fate of human embryonic stem cells originates from primitive endothelium with hemangioblastic properties. Immunity 21, 31-41.

26. Zambidis, E.T., Peault, B., Park, T.S., Bunz, F., and Civin, C.I. (2005) Hematopoietic differentiation of human embryonic stem cells progresses through sequential hematoendothelial, primitive, and definitive stages resembling human yolk sac development. Blood 106, 860-870.

27. Kennedy, M., D'Souza, S.L., Lynch-Kattman, M., Schwantz, S., and Keller, G. (2007) Development of the hemangioblast defines the onset of hematopoiesis in human ES cell differentiation cultures. Blood 109, 2679-2687

28. Lu, S.J., Feng, Q., Caballero, S., Chen, Y., Moore, M.A., Grant, M.B., and Lanza, R. (2007) Generation of functional hemangioblasts from human embryonic stem cells. Nat. Methods 4, 501-509.

29. Wang, Z.Z., Au, P., Chen, T., Shao, Y., Daheron, L.M., Bai, H., Arzigian, M., Fukumura, D., Jain, R.K., and Scadden, D.T. (2007) Endothelial cells derived from human embryonic stem cells form durable blood vessels in vivo. Nat. Biotechnol. 25, 317-318.

30. Kaufman, D.S., Hanson, E.T., Lewis, R.L., Auerbach, R., and Thomson, J.A. (2001) Hematopoietic colony-forming cells derived from human embryonic stem cells. Proc. Natl. Acad. Sci. U. S. A. 98, 10716-10721.

31. Vodyanik, M.A., Bork, J.A., Thomson, J.A., and Slukvin, I.I. (2005) Human embryonic stem cell-derived CD34+ cells: efficient production in the coculture with OP9 stromal cells and analysis of lymphohematopoietic potential. Blood 105, 617-626.

32. Levenberg, S., Golub, J.S., Amit, M., Itskovitz-Eldor, J., and Langer, R. (2002) Endothelial cells derived from human embryonic stem cells. Proc. Natl. Acad. Sci. U. S. A. 99, 4391-4396. Generation of hematopoietic repopulating cells from human embryonic stem cells independent of ectopic HOXB4 expression. J. Exp. Med. 201, 1603-1614. Tian, X., Woll, P.S., Morris, J.K., Linehan, J.L., and Kaufman, D.S. (2006) Hematopoietic engraftment of human embryonic stem cell-derived cells is regulated by recipient innate immunity. Stem Cells 24, 1370-1380.

35. Narayan, A.D., Chase, J.L., Lewis, R.L., Tian, X., Kaufman, D.S., Thomson, J.A., and Zanjani, E.D. (2006) Human embryonic stem cell-derived hematopoietic cells are capable of engrafting primary as well as secondary fetal sheep recipients. Blood 107, 2180-2183.

36. Luckett, W.P. (1978) Origin and differentiation of the yolk sac and extraembryonic mesoderm in presomite human and rhesus monkey embryos. Am. J. Anat. 152, 59-97.

37. Charbord, P., Tavian, M., Humeau, L., and Peault, B. (1996) Early ontogeny of the human marrow from long bones: an immunohistochemical study of hematopoiesis and its microenvironment. Blood 87, 4109-4119.

Ludwig, T.E., Levenstein, M.E., Jones, J.M., Berggren, W.T., Mitchen, E.R., Frane, J.L., Crandall, L.J., Daigh, C.A., Conard, K.R., Piekarczyk, M.S., Llanas, R.A., and Thomson, J.A. (2006) Derivation of human embryonic stem cells in defined conditions. Nat. Biotechnol. 24, 185-187.

39. Levenstein, M.E., Ludwig, T.E., Xu, R.H., Llanas, R.A., VanDenHeuvel-Kramer, K., Manning, D., and Thomson, J.A. (2006) Basic fibroblast growth factor support of human embryonic stem cell self-renewal. Stem Cells 24, 568574.

40. Wang, L., Li, L., Menendez, P., Cerdan, C., and Bhatia, M. (2005) Human embryonic stem cells maintained in the absence of mouse embryonic fibroblasts or conditioned media are capable of hematopoietic development. Blood 105, 4598-4603.

41. Xu, R.H., Peck, R.M., Li, D.S., Feng, X., Ludwig, T., and Thomson, J.A. (2005) Basic FGF and suppression of BMP signaling sustain undifferentiated proliferation of human ES cells. Nat. Methods 2, 185-190.

42. Ying, Q.L., Stavridis, M., Griffiths, D., Li, M., and Smith, A. (2003) Conversion of embryonic stem cells into neuroectodermal precursors in adherent monoculture. Nat. Biotechnol. 21, 183-186.

43. Ying, Q.L., Nichols, J., Chambers, I., and Smith, A. (2003) BMP induction of Id proteins suppresses differentiation and sustains embryonic stem cell self-renewal in collaboration with STAT3. Cell 115, 281-292.

44. Xu, R.H., Chen, X., Li, D.S., Li, R., Addicks, G.C., Glennon, C., Zwaka, T.P., and Thomson, J.A. (2002) BMP4 initiates human embryonic stem cell differentiation to trophoblast. Nat. Biotechnol. 20, 1261-1264.

45. Xiao, L., Yuan, X., and Sharkis, S.J. (2006) Activin A maintains self-renewal and regulates fibroblast growth factor, Wnt, and bone morphogenic protein pathways in human embryonic stem cells. Stem Cells 24, 1476-1486.

46. Vallier, L., Alexander, M., and Pedersen, R.A. (2005) Activin/Nodal and FGF pathways cooperate to maintain pluripotency of human embryonic stem cells. J. Cell Sci. 118, 4495-4509.

47. Brons, I.G., Smithers, L.E., Trotter, M.W., Rugg-Gunn, P., Sun, B., Chuva de Sousa Lopes, S.M., Howlett, S.K., Clarkson, A., Ahrlund-Richter, L., Pedersen, R.A., and Vallier, L. (2007) Derivation of pluripotent epiblast stem cells from mammalian embryos. Nature 448, 191-195.

48. Tesar, P.J., Chenoweth, J.G., Brook, F.A., Davies, T.J., Evans, E.P., Mack, D.L., Gardner, R.L., and McKay, R.D. (2007) New cell lines from mouse epiblast share defining features with human embryonic stem cells. Nature 448, 196-199.

49. Reubinoff, B.E., Pera, M.F., Fong, C.Y., Trounson, A., and Bongso, A. (2000) Embryonic stem cell lines from human blastocysts: somatic differentiation in vitro. Nat. Biotechnol. 18, 399-404.

50. Niwa, H., Burdon, T., Chambers, I., and Smith, A. (1998) Self-renewal of pluripotent embryonic stem cells is mediated via activation of STAT3. Genes Dev. 12, 2048-2060. 
51. Bendall, S.C., Stewart, M.H., Menendez, P., George, D., Vijayaragavan, K., Werbowetski-Ogilvie, T., Ramos-Mejia, V., Rouleau, A., Yang, J., Bosse, M., Lajoie, G., and Bhatia, M. (2007) IGF and FGF cooperatively establish the regulatory stem cell niche of pluripotent human cells in vitro. Nature 448(7157), 1015-1021.

52. Adewumi, O., Aflatoonian, B., Ahrlund-Richter, L., Amit, M., Andrews, P.W., Beighton, G., Bello, P.A., Benvenisty, N., Berry, L.S., Bevan, S., Blum, B., Brooking, J., Chen, K.G., Choo, A.B., Churchill, G.A., Corbel, M., Damjanov, I., Draper, J.S., Dvorak, P., Emanuelsson, K., Fleck, R.A., Ford, A., Gertow, K., Gertsenstein, M., Gokhale, P.J., Hamilton, R.S., Hampl, A., Healy, L.E., Hovatta, O., Hyllner, J., Imreh, M.P., Itskovitz-Eldor, J., Jackson, J., Johnson, J.L., Jones, M., Kee, K., King, B.L., Knowles, B.B., Lako, M., Lebrin, F., Mallon, B.S., Manning, D., Mayshar, Y., McKay, R.D., Michalska, A.E., Mikkola, M., Mileikovsky, M., Minger, S.L., Moore, H.D., Mummery, C.L., Nagy, A., Nakatsuji, N., O'Brien C, M., Oh, S.K., Olsson, C., Otonkoski, T., Park, K.Y., Passier, R., Patel, H., Patel, M., Pedersen, R., Pera, M.F., Piekarczyk, M.S., Pera, R.A., Reubinoff, B.E., Robins, A.J., Rossant, J., RuggGunn, P., Schulz, T.C., Semb, H., Sherrer, E.S., Siemen, H., Stacey, G.N., Stojkovic, M., Suemori, H., Szatkiewicz, J., Turetsky, T., Tuuri, T., van den Brink, S., Vintersten, K., Vuoristo, S., Ward, D., Weaver, T.A., Young, L.A., and Zhang, W. (2007) Characterization of human embryonic stem cell lines by the International Stem Cell Initiative. Nat. Biotechnol. 25, 803-816.

53. Tavian, M., Coulombel, L., Luton, D., Clemente, H.S., Dieterlen-Lievre, F., and Peault, B. (1996) Aorta-associated CD34+ hematopoietic cells in the early human embryo. Blood 87, 67-72.

54. Cortes, F., Debacker, C., Peault, B., and Labastie, M.C. (1999) Differential expression of KDR/VEGFR-2 and CD34 during mesoderm development of the early human embryo. Mech. Dev. 83, 161-164.

55. Vodyanik, M.A., Thomson, J.A., and Slukvin, II. (2006) Leukosialin (CD43) defines hematopoietic progenitors in human embryonic stem cell differentiation cultures. Blood 108, 2095-2105.

56. Asahara, T., Murohara, T., Sullivan, A., Silver, M., van der Zee, R., Li, T., Witzenbichler, B., Schatteman, G., and Isner, J.M. (1997) Isolation of putative progenitor endothelial cells for angiogenesis. Science 275, 964-967.

57. Nishikawa, S.I., Nishikawa, S., Hirashima, M., Matsuyoshi, N., and Kodama, H. (1998) Progressive lineage analysis by cell sorting and culture identifies FLK1+VE-cadherin+ cells at a diverging point of endothelial and hemopoietic lineages. Development 125, 1747-1757.

58. Garlanda, C. and Dejana, E. (1997) Heterogeneity of endothelial cells. Specific markers. Arterioscler. Thromb. Vasc. Biol. 17, 1193-1202.

59. Rafii, S. and Lyden, D. (2003) Therapeutic stem and progenitor cell transplantation for organ vascularization and regeneration. Nat. Med. 9, 702-712.

60. Godin, I. and Cumano, A. (2002) The hare and the tortoise: an embryonic haematopoietic race. Nat. Rev. Immunol. 2, 593-604.

61. Tavian, M., Hallais, M.F., and Peault, B. (1999) Emergence of intraembryonic hematopoietic precursors in the preliver human embryo. Development 126, 793-803.

62. Haar, J.L. and Ackerman, G.A. (1971) A phase and electron microscopic study of vasculogenesis and erythropoiesis in the yolk sac of the mouse. Anat. Rec. 170, 199-223.

63. Murray, P.D.F. (1932) The development in vitro of the blood of the early chick embryo. Proc. R. Soc. Lond. 11, 497521.

64. Sabin, F.R. (1920) Studies on the origin of blood vessels and of red corpuscles as seen in the living blastoderm of the chick during the second day of incubation. Contrib. Embryol. 9, 213-262.

65. Vogeli, K.M., Jin, S.W., Martin, G.R., and Stainier, D.Y. (2006) A common progenitor for haematopoietic and endothelial lineages in the zebrafish gastrula. Nature 443, 337-339.

66. $\quad$ Park, C., Ma, Y.D., and Choi, K. (2005) Evidence for the hemangioblast. Exp. Hematol. 33, 965-970.

67. Jaffredo, T., Nottingham, W., Liddiard, K., Bollerot, K., Pouget, C., and de Bruijn, M. (2005) From hemangioblast to hematopoietic stem cell: an endothelial connection? Exp. Hematol. 33, 1029-1040.

68. Bollerot, K., Pouget, C., and Jaffredo, T. (2005) The embryonic origins of hematopoietic stem cells: a tale of hemangioblast and hemogenic endothelium. APMIS 113, 790-803.

69. Matthews, W., Jordan, C.T., Gavin, M., Jenkins, N.A., Copeland, N.G., and Lemischka, I.R. (1991) A receptor tyrosine kinase cDNA isolated from a population of enriched primitive hematopoietic cells and exhibiting close genetic linkage to c-kit. Proc. Natl. Acad. Sci. U. S. A. 88, 9026-9030.

70. Millauer, B., Wizigmann-Voos, S., Schnurch, H., Martinez, R., Moller, N.P., Risau, W., and Ullrich, A. (1993) High affinity VEGF binding and developmental expression suggest Flk-1 as a major regulator of vasculogenesis and angiogenesis. Cell 72, 835-846.

71. Kabrun, N., Buhring, H.J., Choi, K., Ullrich, A., Risau, W., and Keller, G. (1997) Flk-1 expression defines a population of early embryonic hematopoietic precursors. Development 124, 2039-2048.

72. D'Souza, S.L., Elefanty, A.G., and Keller, G. (2005) SCL/Tal-1 is essential for hematopoietic commitment of the hemangioblast but not for its development. Blood 105, 3862-3870.

73. Shalaby, F., Ho, J., Stanford, W.L., Fischer, K.D., Schuh, A.C., Schwartz, L., Bernstein, A., and Rossant, J. (1997) A requirement for Flk1 in primitive and definitive hematopoiesis and vasculogenesis. Cell 89, 981-990.

74. Shalaby, F., Rossant, J., Yamaguchi, T.P., Gertsenstein, M., Wu, X.F., Breitman, M.L., and Schuh, A.C. (1995) Failure of blood-island formation and vasculogenesis in Flk-1-deficient mice. Nature 376, 62-66.

75. $\quad$ Ema, M., Faloon, P., Zhang, W.J., Hirashima, M., Reid, T., Stanford, W.L., Orkin, S., Choi, K., and Rossant, J. 
(2003) Combinatorial effects of Flk1 and Tal1 on vascular and hematopoietic development in the mouse. Genes Dev. 17, 380-393.

76. Schuh, A.C., Faloon, P., Hu, Q.L., Bhimani, M., and Choi, K. (1999) In vitro hematopoietic and endothelial potential of flk-1(-/-) embryonic stem cells and embryos. Proc. Natl. Acad. Sci. U. S. A. 96, 2159-2164.

77. Hidaka, M., Stanford, W.L., and Bernstein, A. (1999) Conditional requirement for the Flk-1 receptor in the in vitro generation of early hematopoietic cells. Proc. Natl. Acad. Sci. U. S. A. 96, 7370-7375.

78. Ema, M., Takahashi, S., and Rossant, J. (2006) Deletion of the selection cassette, but not cis-acting elements, in targeted Flk1-lacZ allele reveals Flk1 expression in multipotent mesodermal progenitors. Blood 107, 111-117.

79. Motoike, T., Markham, D.W., Rossant, J., and Sato, T.N. (2003) Evidence for novel fate of Flk1+ progenitor: contribution to muscle lineage. Genesis 35, 153-159.

80. Coultas, L., Chawengsaksophak, K., and Rossant, J. (2005) Endothelial cells and VEGF in vascular development. Nature 438, 937-945.

81. Yamashita, J.K., Takano, M., Hiraoka-Kanie, M., Shimazu, C., Peishi, Y., Yanagi, K., Nakano, A., Inoue, E., Kita, F., and Nishikawa, S. (2005) Prospective identification of cardiac progenitors by a novel single cell-based cardiomyocyte induction. FASEB J. 19, 1534-1536.

82. Lee, K.F., Simon, H., Chen, H., Bates, B., Hung, M.C., and Hauser, C. (1995) Requirement for neuregulin receptor erbB2 in neural and cardiac development. Nature 378, 394-398.

83. Linask, K.K. and Lash, J.W. (1993) Early heart development: dynamics of endocardial cell sorting suggests a common origin with cardiomyocytes. Dev. Dyn. 196, 62-69.

84. Iida, M., Heike, T., Yoshimoto, M., Baba, S., Doi, H., and Nakahata, T. (2005) Identification of cardiac stem cells with FLK1, CD31, and VE-cadherin expression during embryonic stem cell differentiation. FASEB J. 19, 371-378.

85. Chen, Y., Amende, I., Hampton, T.G., Yang, Y., Ke, Q., Min, J.-Y., Xiao, Y.-F., and Morgan, J.P. (2006) Vascular endothelial growth factor promotes cardiomyocyte differentiation of embryonic stem cells. Am. J. Physiol. Heart Circ. Physiol. 291, H1653-1658.

86. Moretti, A., Caron, L., Nakano, A., Lam, J.T., Bernshausen, A., Chen, Y., Qyang, Y., Bu, L., Sasaki, M., MartinPuig, S., Sun, Y., Evans, S.M., Laugwitz, K.L., and Chien, K.R. (2006) Multipotent embryonic Isl1(+) progenitor cells lead to cardiac, smooth muscle, and endothelial cell diversification. Cell 127, 1151-1165.

87. Yamashita, J., Itoh, H., Hirashima, M., Ogawa, M., Nishikawa, S., Yurugi, T., Naito, M., Nakao, K., and Nishikawa, S.-I. (2000) Flk1-positive cells derived from embryonic stem cells serve as vascular progenitors. Nature 408, 92-96.

88. Ema, M. and Rossant, J. (2003) Cell fate decisions in early blood vessel formation. Trends Cardiovasc. Med. 13, 254259.

89. Rolny, C., Nilsson, I., Magnusson, P., Armulik, A., Jakobsson, L., Wentzel, P., Lindblom, P., Norlin, J., Betsholtz, C., Heuchel, R., Welsh, M., and Claesson-Welsh, L. (2006) Platelet-derived growth factor receptor-beta promotes early endothelial cell differentiation. Blood 108, 1877-1886.

90. Oberlin, E., Tavian, M., Blazsek, I., and Peault, B. (2002) Blood-forming potential of vascular endothelium in the human embryo. Development 129, 4147-4157.

91. Tavian, M., Robin, C., Coulombel, L., and Peault, B. (2001) The human embryo, but not its yolk sac, generates lympho-myeloid stem cells: mapping multipotent hematopoietic cell fate in intraembryonic mesoderm. Immunity 15, 487-495.

92. Zambidis, E.T., Oberlin, E., Tavian, M., and Peault, B. (2006) Blood-forming endothelium in human ontogeny: lessons from in utero development and embryonic stem cell culture. Trends Cardiovasc. Med. 16, 95-101.

93. Wang, L. (2006) Endothelial and hematopoietic cell fate of human embryonic stem cells. Trends Cardiovasc. Med. 16, 89-94.

94. Zambidis, E., Sinka, L., Tavian, M., Jokubaitis, V., Park, T.S., Simmons, P.J., and Peault, B. (2007) Emergence of human angio-hematopoietic cells in normal development and from cultured embryonic stem cells. Ann. N. Y. Acad. Sci. 1106, 223-232.

95. Ramshaw, H.S., Haylock, D., Swart, B., Gronthos, S., Horsfall, M.J., Niutta, S., and Simmons, P.J. (2001) Monoclonal antibody BB9 raised against bone marrow stromal cells identifies a cell-surface glycoprotein expressed by primitive human hemopoietic progenitors. Exp. Hematol. 29, 981-992.

96. Choi, K. (1998) Hemangioblast development and regulation. Biochem. Cell Biol. 76, 947-956.

97. Ueno, H. and Weissman, I.L. (2006) Clonal analysis of mouse development reveals a polyclonal origin for yolk sac blood islands. Dev. Cell 11, 519-533.

98. Furuta, C., Ema, H., Takayanagi, S., Ogaeri, T., Okamura, D., Matsui, Y., and Nakauchi, H. (2006) Discordant developmental waves of angioblasts and hemangioblasts in the early gastrulating mouse embryo. Development 133, 2771-2779.

99. Kinder, S.J., Loebel, D.A., and Tam, P.P. (2001) Allocation and early differentiation of cardiovascular progenitors in the mouse embryo. Trends Cardiovasc. Med. 11, 177-184.

100. McKinney-Freeman, S.L. and Daley, G.Q. (2007) Towards hematopoietic reconstitution from embryonic stem cells: a sanguine future. Curr. Opin. Hematol. 14, 343-347.

101. Muller, A.M. and Dzierzak, E.A. (1993) ES cells have only a limited lymphopoietic potential after adoptive transfer into mouse recipients. Development 118, 1343-1351.

102. Palacios, R., Golunski, E., and Samaridis, J. (1995) In vitro generation of hematopoietic stem cells from an embryonic 
stem cell line. Proc. Natl. Acad. Sci. U. S. A. 92, 7530-7534.

103. Hole, N., Graham, G.J., Menzel, U., and Ansell, J.D. (1996) A limited temporal window for the derivation of multilineage repopulating hematopoietic progenitors during embryonal stem cell differentiation in vitro. Blood 88, 1266-1276.

104. Burt, R.K., Verda, L., Kim, D.A., Oyama, Y., Luo, K., and Link, C. (2004) Embryonic stem cells as an alternate marrow donor source: engraftment without graft-versus-host disease. J. Exp. Med. 199, 895-904.

105. Kyba, M., Perlingeiro, R.C., and Daley, G.Q. (2002) HoxB4 confers definitive lymphoid-myeloid engraftment potential on embryonic stem cell and yolk sac hematopoietic progenitors. Cell 109, 29-37.

106. Takahashi, K. and Yamanaka, S. (2006) Induction of pluripotent stem cells from mouse embryonic and adult fibroblast cultures by defined factors. Cell 126, 663-676.

107. Okita, K., Ichisaka, T., and Yamanaka, S. (2007) Generation of germline-competent induced pluripotent stem cells. Nature 448, 313-317.

108. Wernig, M., Meissner, A., Foreman, R., Brambrink, T., Ku, M., Hochedlinger, K., Bernstein, B.E., and Jaenisch, R. (2007) In vitro reprogramming of fibroblasts into a pluripotent ES-cell-like state. Nature 448, 318-324.

109. Maherali, N., Sridharan, R., Xie, W., Utikal, J., Eminli, S., Arnold, K., Stadtfeld, M., Yachechko, R., Tchieu, J., Jaenisch, R., Plath, K., and Hochedlinger, K. (2007) Directly reprogrammed fibroblasts show global epigenetic remodeling and widespread tissue contribution. Cell Stem Cell 1, 55-77.

110. Deb-Rinker, P., Ly, D., Jezierski, A., Sikorska, M., and Walker, P.R. (2005) Sequential DNA methylation of the Nanog and Oct-4 upstream regions in human NT2 cells during neuronal differentiation. J. Biol. Chem. 280, 62576260 .

111. Brivanlou, A.H., Gage, F.H., Jaenisch, R., Jessell, T., Melton, D., and Rossant, J. (2003) Stem cells. Setting standards for human embryonic stem cells. Science 300, 913-916.

112. Chambers, I. and Smith, A. (2004) Self-renewal of teratocarcinoma and embryonic stem cells. Oncogene 23, 71507160.

113. Draper, J.S., Pigott, C., Thomson, J.A., and Andrews, P.W. (2002) Surface antigens of human embryonic stem cells: changes upon differentiation in culture. J. Anat. 200, 249-258.

114. Henderson, J.K., Draper, J.S., Baillie, H.S., Fishel, S., Thomson, J.A., Moore, H., and Andrews, P.W. (2002) Preimplantation human embryos and embryonic stem cells show comparable expression of stage-specific embryonic antigens. Stem Cells 20, 329-337.

115. Wang, L., Menendez, P., Cerdan, C., and Bhatia, M. (2005) Hematopoietic development from human embryonic stem cell lines. Exp. Hematol. 33, 987-996.

116. James, D., Levine, A.J., Besser, D., and Hemmati-Brivanlou, A. (2005) TGFbeta/activin/nodal signaling is necessary for the maintenance of pluripotency in human embryonic stem cells. Development 132, 1273-1282.

117. Puceat, M. (2007) TGFbeta in the differentiation of embryonic stem cells. Cardiovasc. Res. 74, $256-261$.

\section{This article should be cited as follows:}

Jezierski, A., Swedani, A., and Wang, L. (2007) Development of hematopoietic and endothelial cells from human embryonic stem cells: lessons from the studies using mouse as a model. TheScientificWorldJOURNAL: TSW Development \& Embryology 7, 1950-1964. DOI 10.1100/tsw.2007.310. 


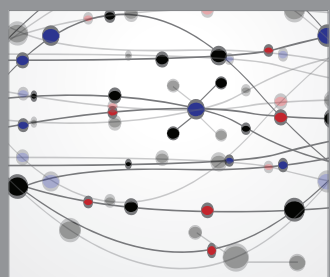

The Scientific World Journal
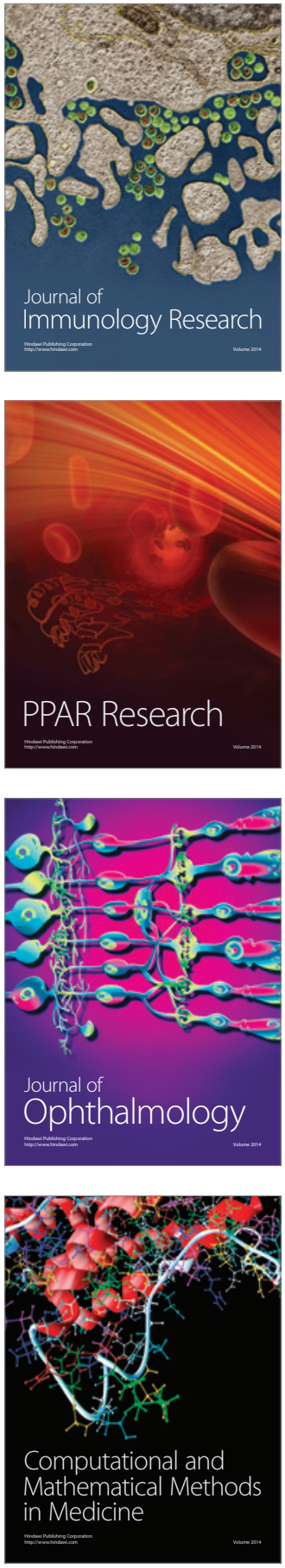

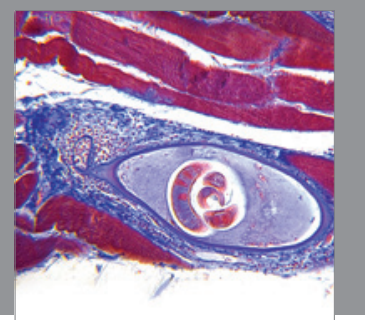

Gastroenterology

Research and Practice
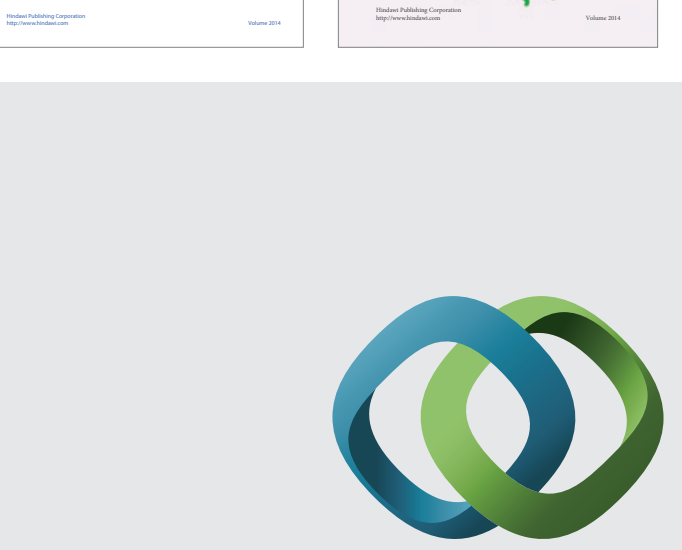

\section{Hindawi}

Submit your manuscripts at

http://www.hindawi.com
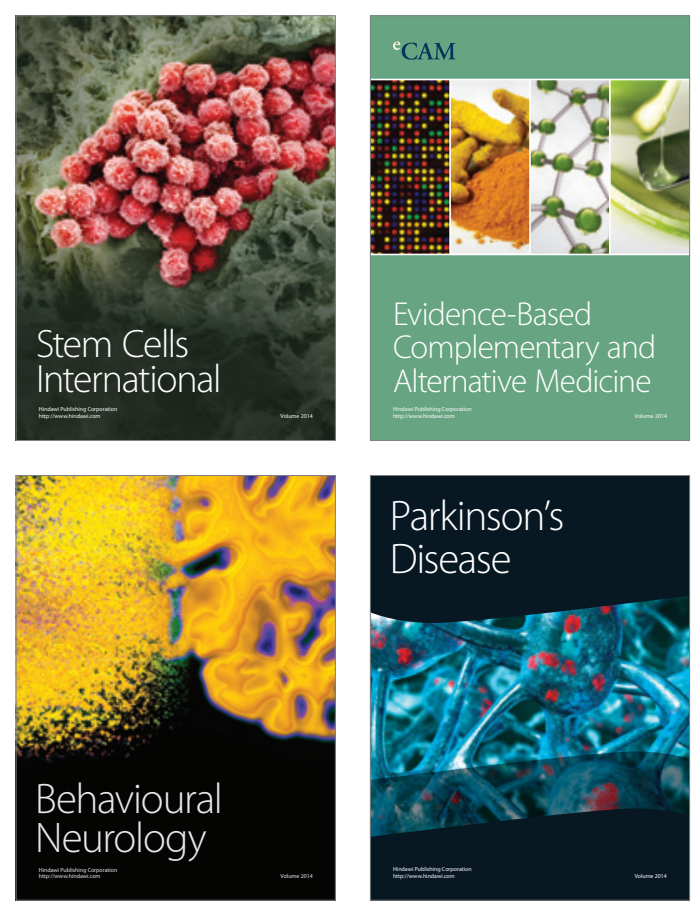

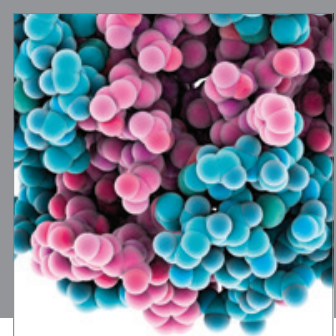

Journal of
Diabetes Research

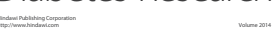

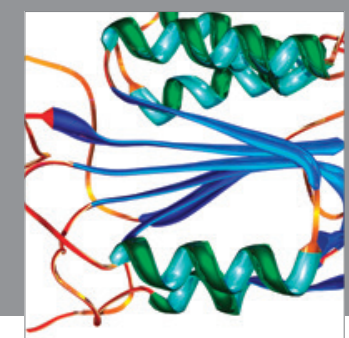

Disease Markers
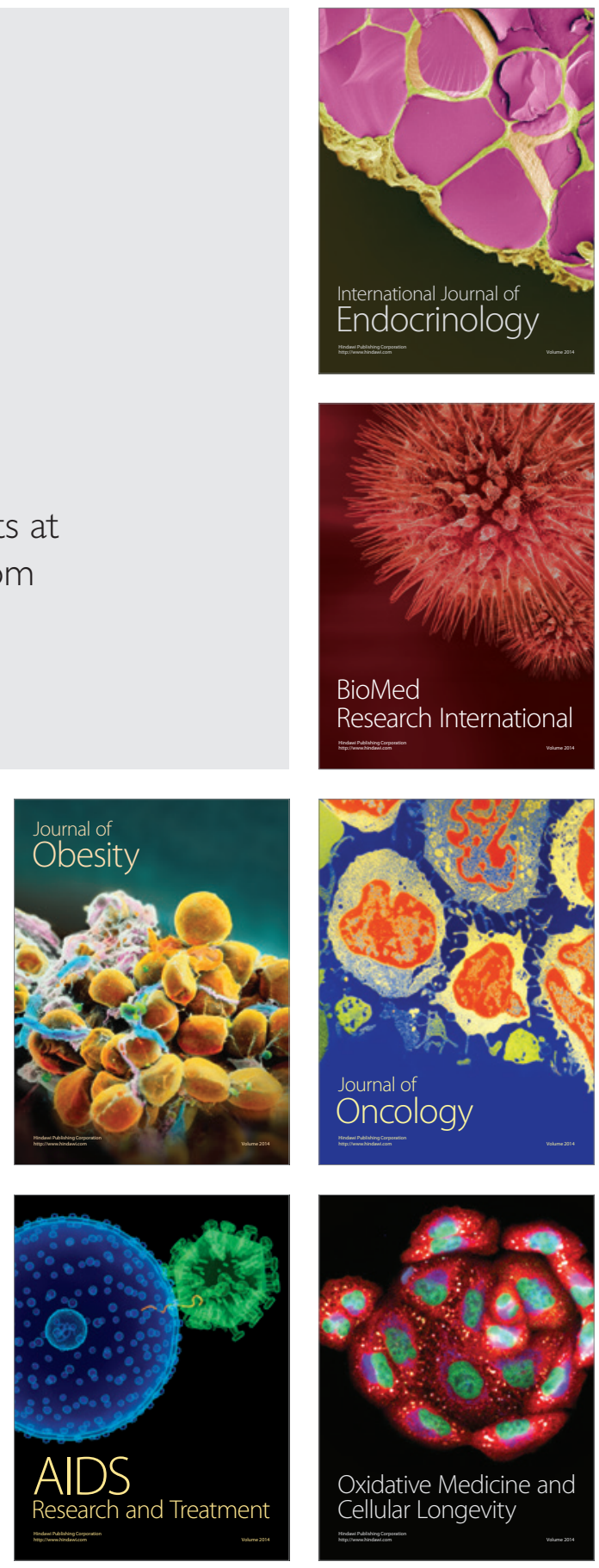